Themanummer: 'Personeel en arbeid in beweging'

Running head: LEERVERMOGEN ALS METACOMPETENTIE

Dries, N., Vantilborgh, T., Pepermans, R., Venneman, L. (2008). Leervermogen als metacompetentie: Ontwikkelbaarheid en loopbaanuitkomsten. Gedrag en Organisatie, $21(4), 265-385$.

Vrije Universiteit Brussel

Arbeids- en Organisatiepsychologie

Pleinlaan 2

1050 Brussel

België

Tel: +32.2.629.39.63.

Fax: +32.2.629.39.48.

E-mail: nicky.dries@vub.ac.be; tim.vantilborgh@vub.ac.be ; roland.pepermans@vub.ac.be;

linda.venneman@vub.ac.be

Dankwoord: De auteurs willen Dr. Ken De Meuse, associate vice president van Lominger

Limited Inc., bedanken voor het kosteloos ter beschikking stellen van het CHOICES

instrument (Lombardo \& Eichinger, 2000). 


\section{Leervermogen als metacompetentie: Ontwikkelbaarheid en loopbaanuitkomsten}

\section{Samenvatting}

De huidige studie, waarin leidinggevenden werknemers die aan hen rapporteren beoordeelden, focuste zich op de volgende twee onderzoeksvragen: (1) is leervermogen ontwikkelbaar; en (2) op welke manier manifesteert leervermogen zich op de werkvloer en in de loopbaan? Wat betreft de eerste onderzoeksvraag vonden we geen effect van leeftijd en werkervaring op leervermogen; we vonden echter wel verbanden met loopbaanvariëteit en opleidingsniveau. Met betrekking tot de tweede onderzoeksvraag zagen we onze hypothesen grotendeels bevestigd. Leervermogen bleek een significante voorspeller te zijn van on-the-job leren en prestatiebeoordelingsscore. Wat betreft de loopbaanuitkomst aantal ontvangen promoties, daarentegen, vonden wij geen volledige bevestiging van de gehypotheseerde verbanden met leervermogen. Uit de data bleek eveneens dat de loopbaanvariëteit van de beoordeelde werknemers eerder laag was, wat impliceert dat hun motivatie om actief op zoek te gaan naar leerervaringen buiten bepaalde geografische, organisationele en functionele grenzen laag was, ongeacht hun leervermogen, en dat het ideaaltype van de flexibele, "boundaryless" loopbaan dus nog geen alomtegenwoordige realiteit is.

Trefwoorden: metacompetentie, leervermogen, loopbaanvariëteit, on-the-job leren 


\section{Learning agility as metacompetency: Developability and career outcomes}

\section{Summary}

The current study let supervisors rate subordinates in terms of learning agility and focused on two research questions: (1) is learning agility developable; and (2) in what way does learning agility manifest itself in the workplace and in the careers of individuals? As regards the first research question, we found no effect of age and work experience on learning agility; we did, however, find effects of career variety and educational level. As for the second research question, we saw our hypotheses largely confirmed. Learning agility was found to be a significant predictor of on-the-job learning and performance rating. As for promotions received however, we did not find full support for the hypothesized relationships with learning agility. Interestingly, the data demonstrated that the career variety of the rated subordinates was rather low, implying that their motivation to actively look for learning experiences outside of certain geographical, organizational and functional boundaries was low, regardless of their learning agility - it thus appears that the ideal type of the flexible, "boundaryless" career is not yet a common reality.

Keywords: metacompetency, learning agility, career variety, on-the-job learning 


\section{Leervermogen als metacompetentie: Ontwikkelbaarheid en loopbaanuitkomsten}

\section{Inleiding}

Het is vandaag de dag een gegeven dat wij ons in een kenniseconomie bevinden waarbinnen het intellectuele kapitaal van organisaties van doorslaggevend belang is voor hun succes. Routinejobs worden geautomatiseerd, zodat talent, in termen van kennis en vaardigheden, belangrijker wordt dan de uitgevoerde taken op zich. De toegenomen complexiteit van de socio-economische omgeving van organisaties vraagt om nieuwe opvattingen rond competentiemanagement (Boudreau \& Ramstad, 2005). Reeds meer dan dertig jaar geleden stelde McClelland (1973) dat onderzoekers en HR-medewerkers zich minder zouden moeten richten op het beoordelen en meten van statische aspecten van het menselijk functioneren op de werkvloer, en meer op het ontwikkelen en gebruiken van instrumenten die er rekening mee houden dat mensen veranderen naarmate ze groeien door ervaringen en opgedane kennis. De recente literatuur over zogenaamde "metacompetenties" lijkt de oproep van McClelland te willen beantwoorden.

In het eerste, theoretische deel van dit artikel geven wij een overzicht van de literatuur rond metacompetenties en leervermogen. In het empirische deel gaan wij dieper in op twee onderzoeksvragen: (1) is leervermogen ontwikkelbaar; en (2) op welke manier manifesteert leervermogen zich op de werkvloer en in de loopbaan?

\section{Van competenties naar metacompetenties}

Daar waar "gewone", "micro-" competenties worden omschreven als de onderliggende kenmerken van personen die leiden tot effectieve en buitengewone prestaties (Boyatzis, 1982), gaat het bij metacompetenties om overkoepelende competenties die zo krachtig zijn, dat zij het vermogen van een persoon voor het verwerven van andere competenties 
beïnvloeden (Briscoe \& Hall, 1999; Burgoyne,1990). Binnen veel hedendaagse organisaties ligt het beoordelen en managen van "gewone" competenties nog steeds aan de basis van hun “human resource management” (HRM) processen (Cheng, Dainty \& Moore, 2005). De meeste grote organisaties hebben formele competentiemodellen ontwikkeld - beschrijvingen van de kennis, vaardigheden, persoonlijke kenmerken en gedragingen die volgens hen vereist zijn om effectief te functioneren. Deze modellen worden typisch gebruikt bij "assessments" van managers, het inschatten van potentieel en talenten, prestatiebeoordelingen, en het ontwikkelen van leiderschapsvaardigheden. Echter, indien competentiemanagement enkel vanuit het selectieperspectief vertrekt, kunnen er (predictieve) validiteitsproblemen ontstaan (McCall, 1998). Binnen een dergelijke visie gaat men er immers vanuit dat werknemers "het al dan niet in zich hebben", en dat organisaties zo snel mogelijk het kaf van het koren dienen te scheiden. Niettegenstaande de utiliteit van het gebruiken van competenties in prestatie- en potentieelbeoordelingsprocessen beschrijft de literatuur een aantal problemen met het gebruiken van de "gewone”, "micro-” competenties (Briscoe \& Hall, 1999; Spreitzer, McCall \& Mahoney, 1997). In de eerste plaats is het niet altijd wenselijk jonge, onervaren werknemers te gaan beoordelen op basis van competentieprofielen die zijn opgesteld naar het model van succesvolle, ervaren werknemers. Men kan immers niet verwachten dat pas afgestudeerde jongeren reeds over competenties op managementniveau beschikken (Briscoe \& Hall, 1999). Ten tweede kan men zich de vraag stellen in hoeverre competentieprofielen die vandaag de dag worden opgesteld predictief kunnen zijn voor prestaties in de steeds onvoorspelbaar wordende toekomst (Athey \& Orth, 1999; Charan \& Colvin, 1999; Spreitzer et al., 1997). Ten derde is men bij het opstellen van een competentieprofiel voor een bepaalde functie of rol vaak niet zeker of men alle relevante competenties heeft kunnen identificeren, en of de gebruikte instrumenten voldoende sensitief en accuraat zijn om de vooropgestelde competenties te kunnen beoordelen (Brown, 1994). In de $21^{\mathrm{e}}$-eeuwse loopbaan, die in 
toenemende mate gekenmerkt wordt door onzekerheid, snelle verandering en "grenzenloosheid” (“boundarylessness”, zie o.a. Arthur \& Rousseau, 1996), zowel over geografische, als organisationele en functionele grenzen heen, zouden metacompetenties dan ook een steeds belangrijkere rol gaan spelen in het "overleven" van individuen in hun loopbaan, en organisaties in de economie.

Een alternatief voor het selectieperspectief wordt geboden door het ontwikkelingsperspectief, dat ervan uitgaat dat het vermogen om te leren uit ervaring de beste voorspeller is van het toekomstig functioneren (McCall, 1998; Spreitzer et al.,1997). Dit idee komt uitgebreid aan bod in de literatuur rond metacompetenties (o.a. Briscoe \& Hall, 1999). Metacompetenties zouden dynamischer en interactiever zijn dan "gewone" competenties. Zij omvatten het kunnen leren, het zich kunnen aanpassen en het kunnen anticiperen daar waar gewone competenties eerder te maken hebben met het op een bepaald moment kunnen aantonen dat men iets "al" kan (Brown, 1994). Briscoe en Hall (1999) gebruiken de analogie van het lezen om het concept van de metacompetentie te verduidelijken - eenmaal een persoon kan lezen, kan hij of zij binnen een veelheid van domeinen bijleren door de verkregen toegang tot alle mogelijke geschreven bronnen van kennis.

Meer onderzoek naar metacompetenties en hoe deze aangewend kunnen worden in de HRM praktijk is echter nodig om bovenstaande veronderstellingen te staven. Tabel 1 geeft alvast een overzicht van concepten gerelateerd aan het begrip - een eerste stap bij het opmaken van een onderzoeksagenda is immers het operationaliseren van het begrip dat men wenst te bestuderen. In de tabel worden verschillende mogelijke benaderingen van metacompetenties weergegeven. Enerzijds vinden we concepten terug zoals "general mental ability" (Wechsler, 1944) en "learning orientation" (Porter \& Tansky, 1999), die een lange traditie kennen binnen het onderwijsveld; anderzijds concepten zoals "adaptive competence" (Hall, 2002) en “employability” (Fugate, Kinicki \& Ashfort, 2004) die gericht zijn op personen in hun 
werkomgeving. Daarenboven wordt door sommige auteurs ook nog eens het onderscheid gemaakt tussen "hard learning" (structureel-technisch leren van expliciete kennis) en "soft learning" (sociaal-relationeel leren van "tacit", ontastbare kennis en denkstijlen), waarbij het eerste veelal aan intelligentie gerelateerd wordt, en het tweede eerder aan aanpassingsvermogen en flexibiliteit (o.a. Eichinger \& Lombardo, 2004).

\section{Voeg hier Tabel 1 in}

In wat volgt zullen wij "leervermogen" ("learning agility", zoals in Lombardo \& Eichinger, 2000) hanteren als operationalisatie van het begrip metacompetentie. Wij kozen voor deze operationalisatie omdat zij specifiek gericht is op de werkomgeving, en zowel aspecten van hard learning als soft learning integreert - meer achtergrondinformatie over het concept volgt in de methodesectie van dit artikel.

\section{Is leervermogen ontwikkelbaar?}

Een aantal auteurs, zoals Karaevli en Hall (2006) in hun artikel rond loopbaanvariëteit, zijn ervan overtuigd dat leervermogen ontwikkeld kan worden. Loopbaanvariëteit wordt omschreven als de accumulatie van diverse ervaringen die een persoon ervaart in zijn of haar loopbaan - zowel diverse ervaringen met betrekking tot functioneel domein (d.w.z. productie, verkoop, management, financiën, wetgeving...) als diverse ervaringen met betrekking tot institutionele context (d.w.z. organisatie, sector, land van tewerkstelling...) (Karaevli \& Hall, 2006). Het uitgangspunt van deze auteurs is dat personen die het grootste deel van hun loopbaan binnen één organisatie of sector hebben doorgebracht, bijvoorbeeld, over een minder brede basis van kennis en vaardigheden beschikken - en daardoor minder geneigd zijn via een diversiteit aan kanalen naar informatie te zoeken en zo bij te leren - dan personen die op een meer gevarieerde ervaring kunnen bogen. Er werden echter nog geen gegevens 
verzameld om deze veronderstellingen te toetsen. In de huidige studie testen we de veronderstellingen van Karaevli en Hall (2006) rond de ontwikkelbaarheid van leervermogen:

$H_{l}$. Loopbaanvariëteit is een significante voorspeller van leervermogen.

Aan de andere kant zijn er ook auteurs die geloven dat "aanleg" de grootste rol speelt voor een effectieve prestatie als leider, manager of professional (Boyatzis et al., 2002). Hoewel onderzoek uitwijst dat competenties ontwikkeld kunnen worden (Boyatzis, Stubbs \& Taylor, 2002), en organisaties wereldwijd miljoenen euro per jaar uitgeven aan het ontwikkelen van competenties, blijkt dit vaak immers een moeizaam proces (Boyatzis \& Saatcioglu, 2008). Indien leervermogen inderdaad een stabiele eigenschap is, zou dat willen zeggen dat leervermogen niet kan verbeterd worden met het ouder worden, het volgen van hogere opleidingen, of met het opdoen van meer (werk)ervaring. Zo stelden Lombardo en Eichinger (2000) dat leervermogen een vorm van intelligentie is in de zin dat "een jonge onervaren persoon over evenveel leervermogen kan beschikken dan een succesvolle vijftiger die reeds veel competenties heeft verworven in de loop der jaren" (p. 321). De auteurs zijn er met andere woorden van overtuigd dat LQ, net zoals IQ, eerder stabiel is. Sternberg, Wagner, Williams en Horvath (1995), die "practical intelligence" hanteerden als doelvariabele, kwamen tot gelijkaardige conclusies. In hun studie werden eveneens geen significante correlaties teruggevonden met leeftijd en aantal jaren werkervaring. In de huidige studie verzamelden wij empirische data over al deze achtergrondvariabelen om zo de tegenstrijdige opvattingen in de literatuur rond leervermogen te kunnen toetsen.

\section{Op welke manier manifesteert leervermogen zich op de werkvloer en in de loopbaan?}

Traditioneel focussen studies naar leren bij werknemers zich op formele trainingsvormen, die gekenmerkt worden door organisatorisch initiatief en uiterst gestructureerde "classroom" leervormen. Recentere studies erkennen echter meer en meer het belang van "on-the-job" ervaringen in het proces van leren op de werkvloer (Cunningham \& Iles, 2002). On-the-job 
leren wordt omschreven als leren dat plaatsvindt door deelname aan echte praktijken op de werkvloer (Gherardi, Nicolini \& Odella, 1998), of nog, als het leren uit ervaringen die zich voordoen wanneer men moet omgaan met de verschillende rollen, verantwoordelijkheden en taken geassocieerd met de job (McCauley, Ruderman, Ohlott \& Morrow, 1994). Twee specifieke kenmerken van on-the-job leren zijn dat interacties met de omgeving (zowel op taakgebied als op interpersoonlijk gebied) de voornaamste bron van leren vormen, en dat dit leren eventueel wel plaats kan vinden binnen, en aangemoedigd worden door de organisatie, maar dat het niet gestructureerd of gepland verloopt en dat de controle over de leerervaring voornamelijk in handen van het individu blijft (Marsick \& Watkins, 1990). Uit onderzoek blijkt dat mensen verschillen in de mate waarin ze leren uit on-the-job ervaringen (Porter \& Tansky, 1996, 1999; Spreitzer et al., 1997); mogelijke oorzaken hiervan zijn verschillen in leerstrategieën (o.a. Spreitzer et al., 1997), verschillen in persoonlijkheids- en motivationele kenmerken (o.a. Van Velsor \& Leslie, 1995), cognitieve capaciteiten (Wouters \& Buyens, 2006), en leervermogen (o.a. Spreitzer et al., 1997).

On-the-job leren is een vrij directe manifestatie van leervermogen; langs de andere kant vinden we in de literatuur ook argumenten terug voor meer indirecte uitkomsten, onder andere op het vlak van prestatie- en potentieelbeoordeling. Zo toonden eerdere studies aan dat het leervermogen van een persoon een significante voorspeller was van prestatiebeoordelingsscore, promoveerbaarheid en of deze persoon als "high potential" (d.w.z. werknemer met uitzonderlijk leiderschapspotentieel) geclassificeerd was of niet (o.a. Connolly \& Viswesvaran, 2002; Lombardo \& Eichinger, 2000; McCall \& Lombardo, 1983; Spreitzer et al., 1997; Sternberg et al., 1995; Wagner \& Sternberg, 1990); men vond zelfs dat leervermogen de beste voorspeller was van prestatie, met een grotere unieke verklarende variantie dan intelligentie, persoonlijkheid, cognitieve vaardigheden, jobtevredenheid en interpersoonlijke stijl (McCauley \& Brutus, 1998). 
Voor de tweede onderzoeksvraag gingen wij ervan uit dat leervermogen zich manifesteert in bepaalde loopbaanuitkomsten zoals een verhoogd on-the-job leren, hogere prestatiebeoordelingsscores en het ontvangen van meer promoties.

\footnotetext{
$H_{2 a}$. Leervermogen is een significante voorspeller van mate van on-the-job leren.

$H_{2 b}$. Leervermogen is een significante voorspeller van prestatiebeoordelingsscore.

$H_{2 c}$ Leervermogen is een significante voorspeller van aantal ontvangen promoties.
}

\section{Methode}

\subsection{Opzet en procedure}

De studie kaderde binnen een groter project rond talent management in Vlaanderen, en een inclusiecriterium was dat deelnemende organisaties over een goed uitgebouwd prestatie- en talent management beleid beschikten. Alle deelnemende organisaties maakten dan ook systematisch gebruik van de HR-gesprekscyclus, persoonlijke ontwikkelingsplannen, en mentoring en coaching. Zeven organisaties namen deel, verspreid over vier sectoren: financiële dienstverlening (41\% van de respondenten), distributie (35\%), ICT (14\%) en telecommunicatie (10\%). De beoordelaars waren leidinggevenden, die de taak kregen de vragenlijst in te vullen over één medewerker die aan hen rapporteerde, en waarvan zij het gevoel hadden de prestatie en het leervermogen goed te kunnen inschatten. Er werd geopteerd voor deze methodiek in plaats van voor zelfbeoordeling om sociale wenselijkheideffecten te verminderen; het instrument dat afgenomen werd (nl. de CHOICES, opgesteld door Lombardo \& Eichinger, 2000 - zie verder) werd oorspronkelijk ook ontworpen als beoordelingsinstrument dat door één of meer directe medewerkers van de beoordeelde werknemer dient ingevuld te worden, en niet zozeer als zelfbeoordelingsinstrument (tenzij in $360^{\circ}$ beoordelingsprocessen gericht op ontwikkeling). Eventuele bias die kan ontstaan door beoordelaars items te laten inschatten waarvan zij geen valide beoordeling kunnen geven (bijvoorbeeld omdat zij nog nooit de gelegenheid hebben gehad om dit specifieke gedrag te 
observeren), wordt in het instrument tegengegaan door de extra antwoordmogelijkheid "Ik weet het niet/ik kan hiervan geen rechtlijnige beoordeling geven".

\subsection{Beoordelaars}

De beoordelaars waren 63 leidinggevenden, die de CHOICES invulden over 63 medewerkers die aan hen rapporteerden op het moment van de dataverzameling. Van de leidinggevenden zelf waren $51(81 \%)$ mannen, en $12(19 \%)$ vrouwen. Zij behoorden vooral tot het middenmanagement $(n=36 ; 57 \%) ; 10$ waren eerstelijnsmanagers $(16 \%), 9$ senior managers (14\%) en 8 behoorden tot het topkader (13\%). De gemiddelde leeftijd van deze leidinggevenden was 43.83 jaar $(s d=7.27)$. Gemiddeld werkten zij al 17.77 jaar binnen hun huidige organisatie $(s d=15.87)$, waarvan ze op het moment van de dataverzameling reeds $4.84(s d=4.05)$ jaren samenwerkten met de medewerker die zij beoordeelden op de CHOICES.

\subsection{Beoordeelde werknemers}

Wat betreft de 63 medewerkers die beoordeeld werden, waren 40 (63\%) mannen en 23 (37\%) vrouwen. Hun gemiddelde leeftijd was 35.05 jaar $(s d=6.55)$. De overgrote meerderheid van de beoordeelde werknemers had hogeschool- (52\%) of universitair onderwijs (32\%) genoten. Zij hadden gemiddeld 12.52 jaar werkervaring $(s d=7.06)$. Bijna de helft van de beoordeelde werknemers oefenden functies uit op een niet-managementniveau $(n=29 ; 46 \%) ; 11$ waren eerstelijnsmanagers (18\%), 14 middenmanagers (23\%), 8 senior managers (11\%) en 1 behoorde tot het topkader $(2 \%)$.

\subsection{Meetinstrumenten ${ }^{1}$}

Leervermogen $(L Q)$ 
Om leervermogen (LQ) te meten, werd gebruik gemaakt van het CHOICES instrument dat ontwikkeld werd door Lombardo en Eichinger (2000) op basis van hun inhoudsanalyses van interview- en surveygegevens verzameld doorheen jarenlange studies van het Center for Creative Leadership (o.a. Lindsey, Homes \& McCall, 1987; McCall, Lombardo \& Morrison, 1988; McCall \& Lombardo, 1983). In een valideringsstudie van het instrument, waarbij meer dan 400 werknemers werden beoordeeld op de 81 items van de CHOICES alsook op prestatie en promoveerbaarheid, werd een vierfactorenstructuur teruggevonden (Lombardo \& Eichinger, 2000, p. 325):

(1) Mentaal leervermogen: Mensen die hoog scoren op deze factor kunnen omschreven worden als aangetrokken tot nieuwe ideeën en complexiteit en als mentaal snel.

Voorbeelditem: "Is in staat zaken met elkaar in verband te brengen die anderen niet zien als gerelateerd" ( $\alpha=.93$ in de oorspronkelijke studie, .96 in de huidige studie).

(2) Mensgericht leervermogen: Mensen die hoog scoren op deze factor gaan actief op zoek naar feedback en staan open voor diverse mensen en standpunten. Voorbeelditem: "Kan ideeën en concepten presenteren in de taal/begrippenwereld van het doelpubliek" $(\alpha=.95$ in de oorspronkelijke studie, .95 in de huidige studie).

(3) Veranderingsgericht leervermogen: Mensen die hoog scoren op deze factor "spelen" graag met nieuwe ideeën en nemen graag deel aan veranderings- en optimaliseringsprocessen. Voorbeelditem: "Introduceert een nieuwe kijk op de dingen in bijna elke discussie" $(\alpha=.95$ in de oorspronkelijke studie, .92 in de huidige studie).

(4) Resultaatgericht leervermogen: Mensen die hoog scoren op deze factor leveren resultaat zelfs wanneer zij iets voor het eerst ondernemen of wanneer de omstandigheden tegenzitten. Voorbeelditem: "Is bereid om hard te werken en persoonlijke opofferingen te maken om vooruit te gaan" ( $\alpha=.96$ in de oorspronkelijke studie, .92 in de huidige studie). 
Alle items dienen beantwoord te worden op een specifieke, gedragsgerichte antwoordschaal:

“0. Ik weet het niet/ik kan hiervan geen rechtlijnige beoordeling geven" (werd bij de analyses gehercodeerd als “missing”); "1. Helemaal niet van toepassing op deze persoon; hij/zij is geblokkeerd op dit vlak, doet dit helemaal niet, doet actief het tegenovergestelde of toont onverschilligheid tegenover dit type gedrag"; "2. Soms van toepassing op deze persoon, maar hij/zij doet dit minder goed of minder vaak dan de meeste personen”; “3. Deze persoon is op dit vlak vergelijkbaar met de meeste mensen"; "4. Deze persoon doet dit beter of vaker dan de meeste mensen"; "5. Deze persoon is één van de duidelijkste voorbeelden van dit gedrag die ik ooit heb gezien".

\section{Loopbaanvariëteit}

Om loopbaanvariëteit te meten werden de twee items gebruikt opgesteld door Karaevli en Hall (2006). Institutionele variëteit werd gemeten met het item "In hoeveel organisaties heeft deze persoon volgens u al gewerkt gedurende zijn/haar gehele loopbaan?”. Ook hier hadden beoordelaars de antwoordoptie "ik weet het niet"; de andere vijf antwoordopties waren "één", "twee", "drie tot vijf", "vijf tot acht", en "meer dan acht". Functionele variëteit werd gemeten met het item "Binnen hoeveel functiedomeinen buiten het huidige heeft deze persoon volgens u ervaring opgedaan gedurende zijn/haar gehele loopbaan?”. Antwoordmogelijkheden waren "geen ervaring", "slechts een beperkte ervaring", "enige ervaring" en "veel ervaring".

\section{On-the-job leren}

Deze variabele werd eveneens gemeten aan de hand van twee items, opgesteld door Spreitzer et al. (1997). Technisch on-the-job leren werd gemeten met het item "Relatief ten opzichte van andere personen in de organisatie, hoe effectief is deze persoon in het leren van nieuwe technieken, functies, diensten of informatie?". Gedragsmatig on-the-job leren werd bevraagd 
met het item "Relatief ten opzichte van andere personen in de organisatie, hoe effectief is deze persoon in het leren van nieuwe gedragingen - nieuwe manieren om met mensen te interageren?". Beide items werden gescoord op een vijfpuntenschaal, nl. "Blijkt extreem traag te leren", "Blijkt traag te leren", "Houdt er een gemiddeld tempo op na”, "Leert snel”, “Leert extreem snel”.

\section{Prestatiebeoordelingsscore}

Prestatiebeoordelingsscore werd bevraagd aan de hand van één item, nl. "Bij de meest recente prestatiebeoordeling werd de prestatie van deze persoon beoordeeld als...".

Antwoordmogelijkheden waren: "voldoet niet aan de verwachtingen", "voldoet aan sommige verwachtingen", “voldoet aan de verwachtingen", "overtreft de verwachtingen", “overtreft de verwachtingen aanzienlijk". De antwoordschalen van dit item waren gebaseerd op "typische" antwoordschalen die organisaties daadwerkelijk gebruiken in prestatie-evaluatieprocessen (Fields, 2002).

\section{Achtergrondvariabelen}

Van de beoordeelde werknemers werd geslacht, leeftijd in jaren, opleidingsniveau, werkervaring in jaren, functieniveau en aantal ontvangen interne promoties bevraagd. Wat betreft de leidinggevenden die de vragenlijst invulden, werd gepeild naar geslacht, leeftijd in jaren, functieniveau en aantal jaren van samenwerking met de beoordeelde werknemer.

\section{Resultaten}

\subsection{Gemiddelden, standaarddeviaties en intercorrelaties}

In de eerste plaats werden beschrijvende analyses uitgevoerd voor elk van de studievariabelen. Algemeen gesteld kwam hieruit een beeld naar voren van eerder lage 
loopbaanmobiliteit. Hoewel de beoordeelde werknemers gemiddeld over 12.52 jaar werkervaring beschikten $(s d=7.06)$, ontvingen zij gemiddeld maar 2.65 promoties in de gehele loopbaan $(s d=1.75)$ en 1.83 promoties binnen hun huidige organisatie $(s d=1.56)$. Daarenboven bleek dat bijna de helft (40\%) van de beoordeelde werknemers slechts voor één organisatie (nl. de huidige) had gewerkt gedurende hun hele loopbaan, en geen enkele in meer dan vijf organisaties, wat aangeeft dat hun institutionele variëteit eerder laag is. De overige beoordeelden hadden voor twee $(30 \%)$ of voor drie tot vijf $(30 \%)$ organisaties gewerkt. Wat functionele variëteit betreft zien we dat de beoordeelde werknemers hierop wel hoger scoren $(m=2.76 ; s d=.84)$.

Tabel 2 geeft een overzicht van de gemiddelden, standaarddeviaties en intercorrelaties van de studievariabelen. Een eerste bevinding is dat de vier subschalen van de CHOICES zeer sterk correleren met elkaar, alsook met de totaalscore van leervermogen. Men zou zich kunnen afvragen of dergelijke hoge correlaties een mogelijke indicatie zijn van het feit dat alle items laden op slechts één factor. Jammer genoeg was het onmogelijk factoranalyse uit te voeren op de data, aangezien wij over minder respondenten dan items beschikten, en zo de assumpties zouden schenden. We hielden de mogelijkheid van een afwijkende factorstructuur echter in het achterhoofd bij het uitvoeren en interpreteren van de overige analyses.

\section{Voeg hier Tabel 2 in}

\subsection{Testen van de hypothesen}

In de correlatietabel vinden we eveneens preliminaire gegevens terug voor het beantwoorden van onze onderzoeksvragen. In verband met onze eerste onderzoeksvraag beschouwen wij naast loopbaanvariëteit ook de achtergrondvariabelen leeftijd, werkervaring en opleidingsniveau om de ontwikkelbaarheid van leervermogen te toetsen. Voor leeftijd en werkervaring vinden we geen significant verband terug met de totaalscore van leervermogen, 
of met de vier subschalen. Voor institutionele loopbaanvariëteit vinden we echter wel een significant verband terug met resultaatgericht leervermogen; voor functionele variëteit vinden we significante verbanden terug met veranderingsgericht en resultaatgericht leervermogen en voor de totaalscore van leervermogen ( $H_{1}$ gedeeltelijk bevestigd); voor opleidingsniveau, ten slotte, vinden we sterke verbanden terug met alle subschalen van leervermogen en met de totaalscore.

De tweede reeks hypothesen, rond loopbaanuitkomsten, worden grotendeels bevestigd: voor technisch on-the-job leren, gedragsmatig on-the-job leren en prestatiebeoordelingsscore worden significante verbanden teruggevonden met alle subschalen van leervermogen en met de totaalscore $\left(H_{2 a}\right.$ en $H_{2 b}$ bevestigd); voor hypothese $H_{2 c}$, rond aantal ontvangen promoties, vinden we slechts gedeeltelijke bevestiging, aangezien voor mentaal en mensgericht leervermogen geen verbanden worden teruggevonden.

Naast Pearson correlaties voerden wij ook een padanalyse uit door middel van structural equation modelling (SEM) om ons theoretisch model in zijn geheel te testen. In Figuur 1 wordt het geteste model weergegeven (geobserveerde variabelen worden voorgesteld door rechthoekige elementen, latente variabelen door ellipsvormige). Leeftijd, werkervaring, opleidingsniveau, en institutionele en functionele loopbaanvariëteit werden uitgezet op de latente variabele "ontwikkelbaarheid"; de vier subschalen van de CHOICES werden uitgezet op de latente variabele "leervermogen"; en technisch on-the-job leren, gedragsmatig on-thejob leren, prestatiebeoordelingsscore en aantal ontvangen interne promoties werden uitgezet op de latente variabele "loopbaanuitkomsten". Voor het merendeel van de relaties tussen deze geobserveerde en latente variabelen werden significante parameterschattingen gevonden (voor meer informatie over de interpretatie van parameterschattingen, zie Kline, 2005) - let wel, dat het hier om verbanden gaat tussen geobserveerde en latente variabelen, terwijl het in de correlatietabel (Tabel 2) gaat om de onderlinge verbanden tussen de geobserveerde 
variabelen. Wanneer we de verbanden tussen de drie latente variabelen in het model beschouwen (die overeenkomen met onze twee onderzoeksvragen) vinden we dat er geen significant verband is tussen ontwikkelbaarheid en leervermogen, terwijl er wel een significant verband is tussen leervermogen en loopbaanuitkomsten.

Voeg hier Figuur 1 in

\subsection{Testen van de beoordelaarsbetrouwbaarheid}

Aangezien alle data in onze studie bekomen werd door leidinggevenden beoordelingen te laten maken over één van hun werknemers, kan men zich twee vragen stellen rond beoordelaarsbetrouwbaarheid: (1) in hoeverre waren deze leidinggevenden in staat om deze variabelen te beoordelen; en (2) in hoeverre speelde "halo bias" (d.w.z. de tendens om bij beoordelingen de algemene indruk die men over iemand heeft te laten weerklinken in alle beoordelingen, onafhankelijk van de dimensie die men beoogt te meten) een rol bij de beoordelingen?

Hoewel het onmogelijk is beoordelaarsfouten volledig uit te sluiten, gingen wij op zoek naar een aantal indicaties van beoordelaarsbetrouwbaarheid. Het kunnen inschatten van de bevraagde variabelen door de leidinggevenden, ten eerste, staat of valt met de kwaliteit van de relatie tussen beoordelaar en beoordeelde werknemer. Zoals reeds eerder vermeld bedroeg de gemiddelde duur van de samenwerking tussen beide partijen ten tijde van de dataverzameling 4.84 jaar, wat een indicatie is dat de beoordelaars-beoordeelden "koppels" samen reeds meerdere beoordelingscycli hadden doorgemaakt. De standaarddeviatie was echter 4.05 jaar, en daarenboven kan men argumenteren dat de duur van de relatie daarom nog niets zegt over de kwaliteit ervan. Met deze bezorgdheid is echter wel rekening gehouden in het onderzoeksopzet, door enkel organisaties op te nemen in de steekproef die konden aantonen over een goed uitgebouwd prestatie- en talent management te beschikken. Een andere 
variabele die wij bekeken om de kwaliteit van de relatie tussen beoordelaars en beoordeelde werknemers na te gaan was het aantal keren dat de antwoordoptie "ik weet het niet/ik kan hiervan geen rechtlijnige beoordeling geven" werd gebruikt. De analyses lijken aan te geven dat de de beoordelaars de werknemers die zij beoordeelden goed kenden. Voor de variabele institutionele loopbaanvariëteit bijvoorbeeld antwoordde geen enkele leidinggevende dat hij of zij geen idee had in hoeveel organisaties de beoordeelde medewerker al werkte. Voor de items van de CHOICES gaven slechts één à twee leidinggevenden per item aan dit niet te kunnen beoordelen, met uitzondering van de items rond leidinggevend of coachend gedrag, waar telkens ongeveer $20 \%$ aangaf deze niet te kunnen beoordelen. Dit is echter eerder een indicatie van betrouwbare antwoordpatronen, aangezien $46 \%$ van de beoordeelde werknemers op niet-managentniveau tewerkgesteld was en het voor een groot deel van hen dus niet mogelijk was dergelijke gedragingen te observeren.

Ten tweede probeerden wij mogelijke beoordelaarsbias of "common method variance" (CMV) in kaart te brengen door middel van structural equation modelling. Wij testten drie modellen op basis van onze data: het eerste model is hetgene weergegeven in Figuur 1 (aan de hand waarvan wij onze hypothesen testten); het tweede model omvatte enkel nog "leervermogen" en "loopbaanuitkomsten" en hun geassocieerde geobserveerde variabelen (aangezien wij in stap 1 vonden dat "ontwikkelbaarheid" en de geassocieerde geobserveerde variabelen geen significant effect op leervermogen hadden; daarenboven zijn al deze variabelen "proxies" van feitelijke data en dus minder onderhevig aan bias); het derde model introduceerde een extra latente variabele die in relatie stond met alle geobserveerde variabelen en die "beoordelaarsbias" moest voorstellen. In Tabel 3 worden de "goodness-of-fit" indices weergegeven voor de drie modellen. We zien dat het model bij elke stap significant verbetert (zie de resultaten van de twee $\chi^{2}$ - verschiltests), wat aangeeft dat het veronderstellen van bias in het model een verbetering oplevert, en dat het dus mogelijk is dat een vorm van bias de 
resultaten verstoorde (voor meer achtergrond over deze analyses, zie Billiet \& McClendon, 2000). De implicaties van mogelijke CMV in ons model worden besproken in het deel rond beperkingen van het huidige onderzoek in de Discussie.

\section{Voeg hier Tabel 3 in}

\section{Discussie}

Eerdere publicaties gaven aan dat leervermogen (LQ), omschreven als een metacompetentie die het mogelijk maakt nieuwe competenties te verwerven wanneer de omgeving daarom vraagt, een cruciale eigenschap is voor individuen en organisaties binnen de context van de $21^{\mathrm{e}}$-eeuwse loopbaan (Burgoyne, 1990; Brown, 1994; Spreizer et al., 1997; Athey \& Orth, 1999; Briscoe \& Hall, 1999; Lombardo \& Eichinger, 2000). Deze context wordt immers gekenmerkt door onzekerheid, snelle evoluties, en het vervagen van geografische, organisationele en functionele grenzen (zie de "boundaryless career", o.a. in Arthur \& Rousseau, 1996). De huidige studie, waarin leidinggevenden werknemers die aan hen rapporteren beoordeelden, focuste zich op de volgende twee onderzoeksvragen: (1) is leervermogen ontwikkelbaar; en (2) op welke manier manifesteert leervermogen zich op de werkvloer en in de loopbaan? Met dit artikel willen wij een bijdrage leveren aan de literatuur rond hedendaagse loopbanen, die steeds minder door planmatigheid en zekerheden, en steeds meer door continue verandering (en de nood aan competenties om met deze continue verandering om te kunnen gaan) gekenmerkt worden (zie o.a. "protean careers", Hall, 1976; en "boundaryless careers”, Arthur \& Rousseau, 1996).

Wat betreft de eerste onderzoeksvraag, naar de ontwikkelbaarheid van leervermogen, vonden we geen effect van leeftijd en werkervaring op leervermogen, net zoals dat het geval was in de studie van Lombardo en Eichinger (2000); we vonden echter wel verbanden tussen leervermogen en opleidingsniveau en institutionele loopbaanvariëteit en functionele 
loopbaanvariëteit, net zoals in Karaevli en Hall (2006). Net zoals in eerdere studies vinden we dus enerzijds indicaties van leervermogen als een eerder stabiele variabele (die niet beïnvloed wordt door leeftijd en werkervaring); anderzijds vinden we indicaties dat leervermogen toch beïnvloed zou kunnen worden door een hogere loopbaanvariëteit of opleidingsniveau. Een alternatieve verklaring voor deze bevindingen is dat de causaliteit voor de laatstgenoemde variabelen misschien omgekeerde is aan de door ons voorgestelde richting. Zo is het bijvoorbeeld heel plausibel dat personen hun leervermogen weliswaar niet kunnen verhogen door hogere studies aan te knopen, maar dat personen met een hoger leervermogen gemiddeld genomen een hoger opleidingsniveau bereiken dan personen met een lager leervermogen. Voor loopbaanvariëteit hetzelfde: vaak van functiedomein of werkgever veranderen heeft waarschijnlijk weinig invloed op het leervermogen, maar het is wel aannemelijk dat personen met een hoger leervermogen meer geneigd zijn naar gevarieerde ervaringen te zoeken waaruit zij kunnen leren. Dit zijn uiteraard slechts veronderstellingen; enkel door middel van longitudinale designs kunnen we echt uitspraken gaan doen over de causaliteit van deze verbanden.

Met betrekking tot de tweede onderzoeksvraag, rond loopbaanuitkomsten gerelateerd aan leervermogen, zagen we onze hypothesen grotendeels bevestigd. Leervermogen bleek een significante voorspeller te zijn van technisch en gedragsmatig on-the-job leren en van prestatiebeoordelingsscore. Wat betreft de loopbaanuitkomst aantal ontvangen promoties, daarentegen, vonden wij geen verbanden met twee subschalen van leervermogen (nl. mentaal en mensgericht leervermogen). Echter, deze resultaten zijn gelijkaardig aan die van andere auteurs (o.a. Lombardo \& Eichinger, 2000). Zij vonden in een valideringsstudie van hun instrument om leervermogen te meten (nl. de CHOICES) ook geen verband tussen leervermogen en promoties; zij vroegen zich af of dit te wijten was aan het feit dat promoties nog vaak gegeven worden op basis van anciënniteit of op basis van de gelijkaardigheid tussen 
de kandidaat en het huidige management (naar dit laatste wordt soms verwezen als “management cloning”).

Een laatste opvallende bevinding is dat uit de data bleek dat de beoordeelde werknemers een eerder lage loopbaanmobiliteit kenden, met weinig promoties en weinig loopbaanvariëteit (vooral wat betreft het veranderen van werkgever, en in mindere mate het veranderen van functiedomein). Deze resultaten geven mogelijk aan dat de motivatie om actief op zoek te gaan naar leerervaringen door het overschrijden van geografische, organisationele en functionele grenzen eerder laag is, ongeacht het leervermogen, en dat het ideaaltype van de flexibele, "boundaryless" loopbaan nog geen alomtegenwoordige realiteit is. Een hoger leervermogen staat dus wel in verband met on-the-job leren, maar in mindere mate met het overschrijden van grenzen die leren kunnen bevorderen. Deze bevindingen gaan dus enigszins in tegen de traditionele (Amerikaanse) notie dat "succesvolle werknemers elke twee jaar promotie maken" (o.a. Ellis \& Heneman, 1990); daarentegen liggen ze wel in lijn met de bevindingen van verschillende Europese studies rond arbeidsmarktmobiliteit. In hun rapportering van het "Eurobarometer" project concluderen Vandenbrande, Coppin en van der Hallen (2006) bijvoorbeeld dat meer dan 25\% van Europeanen slechts één job in hun gehele loopbaan uitvoerden - het Europese gemiddelde bedraagt 3.9 jobs per loopbaan. Wat de Belgische situatie betreft, vonden zij dat ongeveer $30 \%$ van het respondentenpanel nog nooit van organisatie was veranderd, wat ver boven het Europese gemiddelde ligt; deze bevinding ging ook op voor het gemiddeld aantal jaren dat Belgen in een job doorbrengen. We kunnen dus, enigszins tentatief, concluderen dat onze bevindingen overeenstemmen met eerder onderzoek naar de loopbaanmobiliteit van Belgische werknemers. Andere studies gaven ook al aan dat slechts een klein deel van de werkende bevolking aangeeft zich in een boundaryless loopbaan te bevinden, of te willen bevinden - het verlangen naar jobzekerheid, en de nadruk 
op loyaliteit tussen werkgever en werknemer spelen hier een belangrijke rol (Guest \& Mackenzie Davey, 1996; Verbruggen, Sels \& Forrier, 2007).

\subsection{Beperkingen van het huidige onderzoek en suggesties voor verder onderzoek}

De studie gerapporteerd in dit artikel was niet zonder beperkingen; wij identificeerden drie kwesties die aanmanen tot verdere reflectie, en die in het achterhoofd gehouden moeten worden bij het interpreteren en veralgemenen van de gevonden resultaten. Ten eerste was de steekproef van de studie eerder klein $(n=63)$, wat implicaties heeft voor de power en effect size van onze bevindingen. Ook kon hierdoor geen factoranalyse op de CHOICES worden uitgevoerd, aangezien dit instrument meer items bevat dan er respondenten waren; wij kunnen dus noch bevestiging noch ontkrachting van de veronderstelde vierfactorenstructuur voorleggen (Lombardo \& Eichinger, 2000). We vonden wel goede Cronbach's alpha coëfficiënten terug voor elk van de subschalen (we vonden voor elke subschaal alphawaarden terug van hoger dan .90, net zoals dat in de oorspronkelijke studie van Lombardo en Eichinger in 2000 het geval was). Hierbij moeten we echter de bemerking maken dat elke subschaal uit een twintigtal items bestond, en dat het een statistisch gegeven is dat schalen met zoveel items in de regel hoge alphas opleveren. In de analyses namen wij dan ook telkens de totaalscore van de hele schaal mee op. Een tweede mogelijke beperking, die in de resultatensectie al uitgebreid aan bod kwam, is die van de mogelijke "halo bias" die in ons opzet sloop. Uit onze SEM analyses van common method variance bleek dat het veronderstellen van een vorm van bias in het model dit model verbeterde, wat impliceert dat er een onderliggende variabele is die meespeelt in de beoordelingen van de leidinggevenden. Indien er sprake zou zijn van halo bias (dit kunnen we slechts veronderstellen, want de analyses geven slechts aan dat er "een" onderliggende beïnvloedende factor is, niet dewelke dit juist is) zou dit kunnen betekenen dat de leidinggevenden in onze studie personen die beter on-the-job leren, hogere prestatiescores 
en meer promoties ontvangen automatisch ook hoger scoorden op de CHOICES. Het is echter moeilijk om common method variance helemaal te weren uit surveystudies. Vaak wordt het probleem helemaal niet besproken in artikels; in dit artikel hebben wij getracht dit probleem concreet in kaart te brengen door een latente variabele "beoordelaarsbias" mee op te nemen in ons model. Daarenboven is halo bias iets wat ook heel sterk speelt in de praktijk van prestatieen potentieelbeoordeling, zodat het moeilijk is af te leiden of eventuele bias wel helemaal aan het opzet van onze studie te wijten is. Ten slotte zou men kunnen zeggen dat er een mogelijke paradox in dit artikel terug te vinden is: in de inleiding ijveren we voor een ontwikkelingsperspectief op competentiemanagement, terwijl uit onze bevindingen blijkt dat leervermogen niet toeneemt met leeftijd of werkervaring. We vonden wel een verband tussen leervermogen, opleidingsniveau en loopbaanvariëteit, maar het is niet duidelijk welke variabelen hier oorzaak, en welke gevolg zijn. We stellen voor dat het selectie- en het ontwikkelingsperspectief niet wederzijds exclusief hoeven te zijn: waarom niet leervermogen mee opnemen als selectiecriterium, naast gewone, microcompetenties? Daarenboven is leervermogen een functie van zowel "kunnen" en "willen" leren - daar waar het "kunnen" mogelijk eerder dispositioneel is, zou het "willen" misschien beïnvloed kunnen worden door interventies (op eigen initiatief of van de organisatie uit) die de motivatie om te leren verhogen.

Naar verder onderzoek toe bieden vooral longitudinale designs een interessante piste. Door het opvolgen van mensen doorheen de tijd, en doorheen hun leerervaringen, kan men echt op een causale manier gaan onderzoeken hoe stabiel LQ eigenlijk is en of personen met een hoger leervermogen inderdaad gemakkelijker nieuwe competenties verwerven. Het onderzoeken van populaties die op korte tijd veel leerervaringen ondergaan, zoals de zogeheten "management trainees", kan een goed uitgangspunt vormen voor dergelijke longitudinale designs, aangezien zulke trajecten expliciet gericht zijn op het verwerven van 
een groot aantal competenties op korte tijd, om zo sneller door te groeien naar managementposities. Longitundinaal onderzoek kan eveneens interessant zijn om conflicten tussen korte- en langetermijnoverwegingen in kaart te brengen. Het is bijvoorbeeld mogelijk dat de prestatie op korte termijn in het gedrang komt wanneer personen teveel bezig zijn met het verwerven van competenties waarvan het nut pas op langere termijn zichtbaar wordt. Omgekeerd is het mogelijk dat het aanleren van nieuwe competenties verhinderd wordt door allerlei kortetermijndoelstellingen die als prioritair worden gezien. Het nemen van risico's kan bijvoorbeeld de prestatie hinderen op korte termijn, maar leren op langere termijn faciliteren (Kanfer \& Ackerman, 1989).

\subsection{Praktische implicaties}

Verschillende auteurs (o.a. Lombardo \& Eichinger, 2000; Porter \& Tansky, 1999) beschreven reeds positieve uitkomsten van leervermogen in de vorm van observeerbaar gedrag op de werkvloer: personen met een hoog leervermogen staan gretig tegenover leren over zichzelf, anderen en ideeën; ze gaan op zoek naar feedback en zijn bereid veranderingen aan te brengen op basis van deze feedback; ze zijn geïnteresseerd in het helpen van andere personen op het vlak van leren en experimenteren; ze zijn volhardend en flexibel; ze staan open voor diverse soorten mensen en ideeën, zijn grotendeels zelfmanagend en staan over het algemeen open voor trainings- en ontwikkelingsinitiatieven.

Het hanteren van metacompetenties kan zijn nut bewijzen voor de HRM-praktijk. Ten eerste kan het leervermogen van pas afgestudeerde (potentiële) werknemers gebruikt worden om de prestaties, en het toekomstige potentieel van deze personen te beoordelen. Bij "gewone" microcompetenties ligt dit moeilijker aangezien hun predictieve waarde afhangt van het feit of zij nog relevant zullen zijn in de toekomst, en omdat het moeilijk is in te schatten in hoeverre men in staat is deze competenties te ontwikkelen en op welke termijn, zonder informatie over 
het leervermogen (Briscoe \& Hall, 1999). Uit een studie van Briscoe en Hall (1999) naar de competentiemanagementsystemen van 31 organisaties bleek dat deze er gemiddeld 4.1 jaar over deden om hun competentieraamwerken telkens weer up-to-date te brengen, veel te lang dus om aan de snel veranderende eisen van hun socio-economische omgeving tegemoet te kunnen komen. De auteurs concludeerden dat werknemers metacompetenties nodig hebben, zowel om de "just-in-time" competenties te ontwikkelen die ze nodig hebben om zich aan te passen aan continue, kortetermijnuitdagingen als om persoonlijke competenties te ontwikkelen die hen kunnen helpen door te zetten doorheen opeenvolgende golven van verandering (Briscoe \& Hall, 1999). Ten tweede kan leervermogen helpen prestatie- en potentieelbeoordelingen van elkaar te onderscheiden, een onderscheid dat nu minder duidelijk is (zie de hiervoor besproken "halo bias") aangezien men vaak voor beide processen microcompetenties hanteert. Ten derde stelt het beoordelen van leervermogen organisaties in staat mensen met doorgroeipotentieel op jonge leeftijd al te identificeren, waardoor trainingsen opleidingstrajecten meer kans hebben om te slagen. Uit onderzoek (o.a. Karaevli \& Hall, 2006) blijkt immers dat zulke trajecten (o.a. jobrotaties, mentoringtrajecten of het volgen van specifieke opleidingen) vaak niet de beoogde resultaten genereren. De oorzaak hiervan wordt dan veelal gezocht bij de kwaliteit van de ontwikkelingstrajecten - terwijl een andere verklaring zou kunnen zijn dat niet alle deelnemers aan zulke trajecten een even groot leervermogen bezitten. Organisaties moeten zich ervan bewust zijn dat zij zelf barrières kunnen creëren in hun structuur die het leren van werknemers aanzienlijk bemoeilijken. De volgende barrières verhinderen vaak de transfer van leervermogen naar leergedrag (bijvoorbeeld on-the-job leren): te snel of te traag moeten evolueren; een gebrek aan ontwikkelingsmogelijkheden, structuren of ondersteuning; en "fysieke" beperkingen zoals een gebrek aan tijd, ruimte of budgetten. Organisaties moeten ervoor zorgen dat hun cultuur en hun managers het belang dat zij hechten aan leren uitstralen (bijvoorbeeld door 
leerobjectieven te verbinden aan beloningsstrategie). De focus dient van "training" (in de vorm van "classroom" aciviteiten) naar "ontwikkeling" (in de vorm van een brede waaier aan activiteiten, zowel on-the-job, off-the-job, formeel als informeel) te verschuiven. De betrokkenheid van eerstelijnsmanagers, collega's en andere betrokken partijen (bijvoorbeeld het gezin van de werknemer) is eveneens een doorslaggevende factor om de transfer van leervermogen naar leergedrag te stimuleren (Marsick \& Watkins, 1997; Wouters \& Buyens, 2006). Ook individuen kunnen barrières tot leren vertonen, onder andere wanneer zij hun verdere ontwikkeling niet als persoonlijke prioriteit zien, geblokkeerd worden door onzekerheid en faalangst, ongemotiveerd zijn (al dan niet doordat ze de mogelijke beloningen niet inzien), of slechte ervaringen hadden in het verleden die leren in het heden ontmoedigen. Uit onderzoek blijkt dat "ontsporing" in de loopbaan (d.w.z. het onvermogen van het individu om mee te evolueren met de eisen van zijn of haar job doorheen de tijd) vaak veroorzaakt wordt doordat mensen op een bepaald moment niet meer (kunnen of willen) bijleren (Leslie and Van Velsor, 1996; McCall and Lombardo, 1983).

Verder onderzoek is nodig om te bepalen welke ontwikkelingsinitiatieven de beste resultaten garanderen voor verschillende groepen van werknemers. Door de diversiteit van personen in loopbanen te onderkennen, zowel wat betreft "kunnen leren" als "willen leren", kan men competentieontwikkelingstrajecten dan zo gaan sturen, dat zij voor alle betrokken partijen optimaal renderen. 
Tabel 1 Overzicht van concepten gerelateerd aan het begrip "metacompetentie"

1 Wechsler (1944)

2 Kolb (1984)

3 Wagner \& Sternberg (1991)

4 Sloan (1994)

5 Bar-On (1997)

6 Spreitzer, McCall \& Mahoney (1997)

7 Taylor (1997)

8 London \& Smither (1999)

9 Murphy \& Jackson (1999)

10 Porter \& Tansky (1999)

11 Lombardo \& Eichinger (2000)

12 Pulakos, Arad, Donovan, \& Plamondon (2000) intelligence/general mental ability

experiential learning

practical intelligence/tacit knowledge

versatility

emotional intelligence

the ability to learn from experience

learning potential

continuous learning

role flexibility

learning orientation

learning agility

adaptive performance

\section{Definitie}

"the aggregate or global capacity of the individual to act purposefully, to think rationally and to deal effectively with his environment” (p. 3)

"the process whereby knowledge is created through the transformation of experience; knowledge results from the combination of grasping and transforming experience" (p. 41)

"practical know-how that rarely is expressed openly or taught directly" (p. 1)

"adapting and performing effectively across a wide range of new situations and changing contexts" (p. 28)

"an array of noncognitive capabilities, competencies and skills that influence one's ability to succeed in coping with environmental demands and pressures" (p. 14).

"seek opportunities to learn, seek feedback, are culturally adventurous, are open to criticism, and are flexible" (p. 13)

"an individual's fundamental cognitive capabilities and potentialities used to master new cognitively demanding material in a formal educational or training context. Learning potential does not focus on acquired skills or abilities but on the ability to learn new skills and gain knowledge" (p. 1)

"seek information to identify skill gaps, recognize areas to improve current performance, keep up with advances in their profession, and anticipate how changes elsewhere in the firm and the industry may affect work demands and skill requirements (p. 4)

"the willingness and ability to adapt to diverse and changing expectations" (p. 345)

"receptiveness to training and development, reactions to feedback, and the potential to be selfmanaging" (p.50)

"the willingness and ability to learn new competencies in order to perform under first-time, tough, or different conditions" (p. 323)

"handling emergencies or crisis situations; learning work tasks, technologies, and procedures ; handling work stress; demonstrating interpersonal adaptability; displaying cultural adaptability; solving problems creatively; dealing effectively with unpredictable or changing work situations; and demonstrating physically oriented adaptability" (p. 617) 


\section{Hall (2002)}

14 Fugate, Kinicki \& Ashfort (2004)

15 White, Mueller-Hanson, Dorsey, Pulakos, Wisecarver, \& Deagle (2005)

16 Kaiser, Lindberg \& Craig (2007)

\section{adaptive competence}

employability

adaptability

behavioral flexibility "developing appropriate behavioral responses to environment" (p. 208)

"a host of person-centered constructs that combine synergistically to help workers effectively adapt to the myriad of work-related changes occurring in today's economy" (p. 15)

"an effective change in response to an altered situation" (p. 2)

a capability to adapt to new, different, or changing requirements. The range of specific behaviors one is capable of enacting is less important here than the generic tendency to vary one's approach" (p. 41)

Noot. Wij kozen ervoor deze concepten en hun definities niet te vertalen omdat hierdoor de inhoudsvaliditeit in het gedrang zou kunnen komen. 
Tabel 2 Gemiddelden, standaarddeviaties en intercorrelaties van de studievariabelen $(n=63)$

\begin{tabular}{|c|c|c|c|c|c|c|c|c|c|c|c|c|c|c|c|c|}
\hline & $\mathbf{M}$ & SD & 1 & 2 & 3 & 4 & 5 & 6 & 7 & 8 & 9 & 10 & 11 & 12 & 13 & 14 \\
\hline 1 Leervermogen (LQ) ${ }^{\mathrm{b}}$ & 3.75 & .65 & - & & & & & & & & & & & & & \\
\hline 2 Mentaal leervermogen ${ }^{b}$ & 3.35 & .63 & $.94 * *$ & - & & & & & & & & & & & & \\
\hline 3 Mensgericht leervermogen ${ }^{b}$ & 3.27 & .59 & $.89^{* *}$ & $.85^{* *}$ & - & & & & & & & & & & & \\
\hline 4 Veranderingsgericht leervermogen ${ }^{b}$ & 4.16 & .73 & $.96^{* *}$ & $.89 * *$ & $.79 * *$ & - & & & & & & & & & & \\
\hline 5 Resultaatgericht leervermogen ${ }^{b}$ & 4.21 & .85 & $.93 * *$ & $.80 * *$ & $.72 * *$ & $.88^{* *}$ & - & & & & & & & & & \\
\hline 6 Leeftijd ${ }^{\mathrm{d}}$ & 35.05 & 6.55 & .00 & -.06 & -.17 & .00 & .16 & - & & & & & & & & \\
\hline 7 Werkervaring ${ }^{d}$ & 12.52 & 7.06 & -.039 & -.11 & -.19 & -.02 & .11 & $.95^{* *}$ & - & & & & & & & \\
\hline 8 Opleidingsniveau ${ }^{\mathrm{c}}$ & 9.05 & 1.21 & $.39 * *$ & $.41^{* *}$ & $.30^{*}$ & $.39^{* *}$ & $.36^{* *}$ & -.19 & $-.25^{*}$ & - & & & & & & \\
\hline 9 Institutionele loopbaanvariëteit ${ }^{b}$ & 1.90 & .84 & .25 & .15 & .19 & .24 & $.29 *$ & $.26^{*}$ & $.33 * *$ & -.14 & - & & & & & \\
\hline 10 Functionele loopbaanvariëteit ${ }^{a}$ & 2.76 & .84 & $.29 *$ & .19 & .18 & $.31 *$ & $.38 * *$ & $.35 * *$ & $.32 *$ & .03 & .19 & - & & & & \\
\hline 11 Technisch on-the-job leren ${ }^{b}$ & 3.95 & .71 & $.65^{* *}$ & $.73 * *$ & $.51 * *$ & $.61 * *$ & $.58^{* *}$ & -.16 & -.24 & $.44 * *$ & .07 & .14 & - & & & \\
\hline 12 Gedragsmatig on-the-job leren ${ }^{b}$ & 3.63 & .68 & $.54 * *$ & $.52 * *$ & $.62 * *$ & $.50^{* *}$ & $.40 * *$ & $-.33^{* *}$ & $-.35^{* *}$ & $.26^{*}$ & .11 & .19 & $.57 * *$ & - & & \\
\hline 13 Prestatiebeoordelingsscore ${ }^{b}$ & 3.76 & .73 & $.60 * *$ & $.54 * *$ & $.64 * *$ & $.55^{* *}$ & $.53 * *$ & $-.30 *$ & $-.32 *$ & $.30^{*}$ & -.04 & .22 & $.60 * *$ & $.73^{* *}$ & - & \\
\hline 14 Aantal ontvangen interne promoties ${ }^{\mathrm{d}}$ & 1.83 & 1.56 & $.31 *$ & .25 & .13 & $.34 * *$ & $.38 * *$ & $.43 * *$ & $.36^{* *}$ & .03 & -.09 & $.42 * *$ & .09 & .06 & .15 & - \\
\hline
\end{tabular}

Noot. ${ }^{*} p<.005 ;{ }^{* *} p<.001 ;{ }^{\mathrm{a}} 4$-puntenschaal, ${ }^{\mathrm{b}} 5$-puntenschaal, ${ }^{\mathrm{c}} 10$-puntenschaal, ${ }^{\mathrm{d}}$ open vraag 


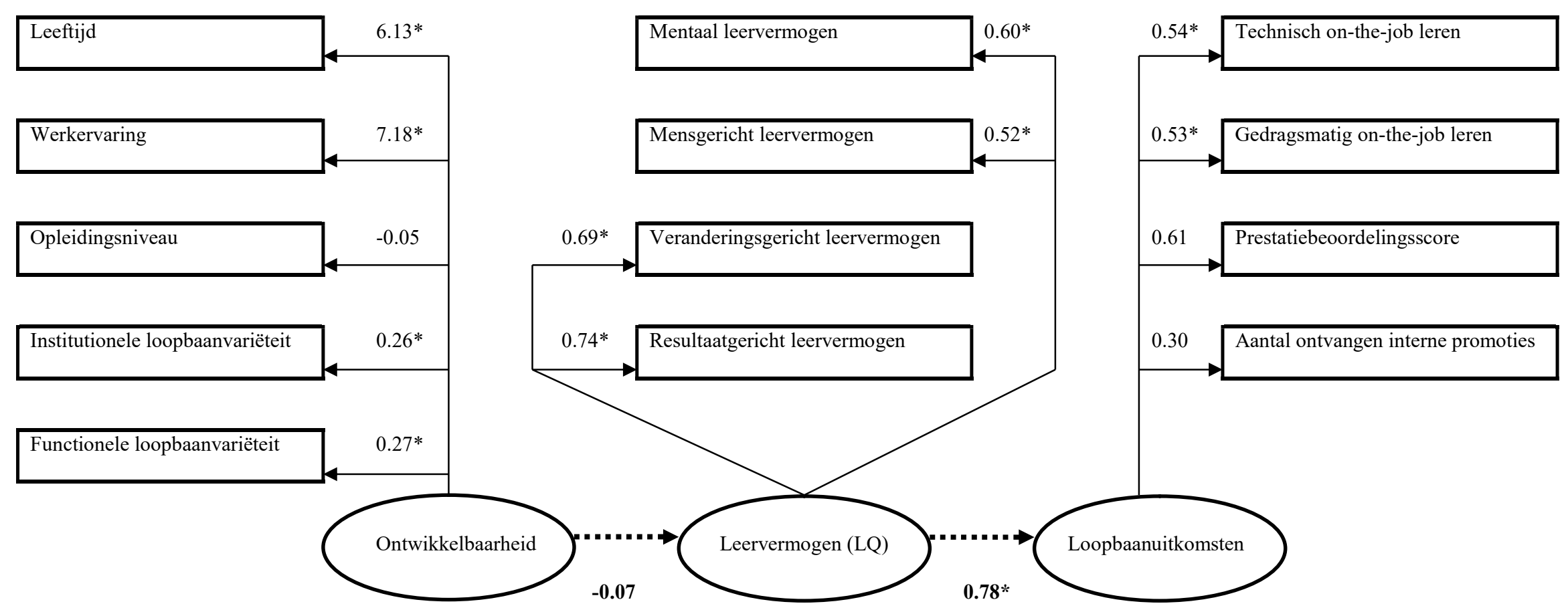

Noot. $* p<.05$

Figuur 1 Paddiagram van de studievariabelen, verkregen via structural equation modelling (SEM) 
Tabel 3 "Goodness-of-fit" statistieken uit de SEM analyses $(n=63)$

\begin{tabular}{lccc}
\hline & Model 1 & Model 2 & Model 3 \\
\hline Satorra-Bentler $\chi^{2}$ & $\chi^{2} S B(63)=130.93 ; \mathrm{p}=.000$ & $\chi^{2} S B(19)=27.92 ; \mathrm{p}=.085$ & $\chi^{2} S B(18)=19.31 ; \mathrm{p}=0.37$ \\
CFI & 0.86 & 0.99 & 1.00 \\
RMR & 0.74 & 0.069 & 0.069 \\
RMSEA & 0.13 & 0.087 & 0.034 \\
$\chi^{2}$ - verschiltest & - & $\chi^{2} D(44)=103.01 ; \mathrm{p}=.000$ & $\chi^{2} D(1)=8.61 ; \mathrm{p}=.005$ \\
\hline
\end{tabular}




\section{Literatuur}

Arthur, M.B., \& Rousseau, D.M. (1996). The boundaryless career: A new employment principle for a new organizational era. New York: Oxford University Press.

Athey, T.R. \& Orth, M.S. (1999). Emerging competency methods for the future. Human Resource Management, 38, 215-226.

Bar-On, R. (1997). The Bar-On Emotional Quotient Inventory (EQ-i): A Test of Emotional Intelligence. Toronto, Canada: Multi-Health Systems.

Billiet J. \& McClendon, M.J. (2000). Modeling Acquiescence in Measurement Models for Two Balanced Sets of Items. Structural Equation Modeling, 7(4),608-628.

Boudreau, J.W. \& Ramstad, P.M. (2005). Talentship, Talent Segmentation, and Sustainability: A New HR Decision Science Paradigm for A New Strategy Definition. Human Resource Management, 44 (2), 129-136.

Boyatzis, R.E. (1982). The competent manager: A model for effective performance. New York: John Wiley \& Sons.

Boyatzis, R. E., \& Saatcioglu, A. (2008). A twenty-year view of trying to develop emotional, social and cognitive intelligence competencies in graduate management education. Journal of Management Development, 27(1), 92-108.

Boyatzis, R.E., Stubbs, E.C. \& Taylor, S.N. (2002). Learning cognitive and emotional intelligence competencies through graduate management education. Academy of Management Journal on Learning and Education, 1(2), 150-162.

Briscoe, J.P. \& Hall, D.T. (1999). Grooming and picking leaders using competency frameworks: Do they work? An alternative approach and new guidelines for practice. Organizational Dynamics, 28, 37-52.

Brown, R.B. (1994). Reframing the competency debate. Management knowledge and metacompetence in graduate education. Management Learning, 25, 289-299. 
Burgoyne, J. (1990). Doubts about competency. In M. Devine (Ed.), The photofit manager (20-26). London: Unwin-Hyman.

Charan, R. \& Colvin, G. (1999). Why CEOs fail. Fortune International, 139, 68-69.

Cheng, M., Dainty, A. \& Moore, D. (2005). Towards a multidimensional competency-based managerial performance framework: A hybrid approach. Journal of Managerial Psychology, 20 (5), 380-396.

Connolly, J.A., \& Viswesvaran, C. (2002). Assessing the Construct Validity of a Measure of Learning Agility. Presented at the Seventeenth Annual Conference of the Society for Industrial and Organizational Psychology, Toronto, Canada.

Cunningham, P. \& Iles, P. (2002). Managing learning climates in a financial services organisation. Journal of Management Development, 21 (6), 477 - 492.

Eichinger, R.W. \& Lombardo, M.M. (2004). Learning agility as a prime indicator of potential. Human Resource Planning, 27, 12-15.

Ellis, R. \& Heneman, H.G. (1990). Career pattern determinants of career success for mature managers. Journal of Business and Psychology, 5, 2-24.

Fields, G.S. (2002). Predicting potential for promotion: How the data in human resource information systems can be used to help organizations gain competitive advantage (CAHRS Working Paper \#02-14). Ithaca, NY: Cornell University, Center for Advanced Human Resource Studies.

Fugate, M., Kinicki, A.J., \& Ashforth, B.E. (2004). Employability: A psycho-social construct, its dimensions, and applications. Journal of Vocational Behaviour, 65, 14-38.

Gherardi, S., Nicolini, D. \& Odella, F. (1998). Toward a Social Understanding of How People Learn in Organizations: The Notion Of Situated Curriculum. Management Learning, 3, 273-297. 
Guest, D. \& Mackenzie Davey, K. (1996). Don't write off the traditional career. People Management, 2, 22-25.

Hall, D.T. (1976). Careers in organizations. Pacific Pallisades : Goodyear

Hall, D.T. (2002). Careers in and out of organizations. Thousand Oaks, CA: Sage.

Kaiser, R. B., Lindberg, J. T., \& Craig, S. B. (2007). Assessing the flexibility of managers: A comparison of methods. International Journal of Selection and Assessment, 15, 40-55.

Kanfer, R., \& Ackerman, P. L. (1989). Motivation and cognitive abilities: An integrative/aptitude-treatment interaction approach to skill acquisition. Journal of Applied Psychology - Monograph, 74, 657-690.

Karaevli, A. \& Hall, D.T. (2006). How career variety promotes the adaptability of managers: A theoretical model. Journal of Vocational Behavior, 69, 359-373.

Kline, R.B. (2005). Principles and Practice of Structural Equation Modeling. New York: Guilford Press.

Kolb, D.A. (1984). Experiential Learning: experience as the source of learning and development. New Jersey: Prentice-Hall.

Leslie, J. \& Van Velsor, E. (1996). A look at derailment today: North America and Europe. Greensboro: Center for Creative Leadership.

Lindsey, E., Homes, V. \& McCall, M.W. (1987). Key events in executives' lives. Technical report 32. Greensboro, NC: Center for Creative Leadership.

Lombardo, M.M. \& Eichinger, L.W. (2000). High potentials as high learners. Human Resource Management, 39, 321-329.

London, M., Smither, J.W. (1999), "Empowered self-development and continuous learning", Human Resource Management, Vol. 38 pp.3-15

Marsick, V. J. \& Watkins, K. (1990). Informal and Incidental Learning in the Workplace. London: Routledge. 
McCall, M.W. Jr. \& Lombardo, M.M. (1983). What makes a top executive? Psychology Today, 17, 26-31.

McCall, M.W., Lombardo, M. M. \& Morrison, A. M. (1988). The lessons of experience: How successful executives develop on the job. Lanhan, MD: Lexington Books.

McCall, M.W. (1998). High Flyers: Developing the next generation of leaders. Cambridge, MA: Harvard Business School Press.

McCauley, C. D., Ruderman, M. N., Ohlott, P. J., \& Morrow, J E. (1994). Assessing the developmental components of managerial jobs. Journal of Applied Psychology, 79(4), 544-560.

McClelland, D.C. (1973). Testing for competence rather than for "intelligence". American Psychologist, 28, 1-14.

Murphy, P. R., \& Jackson, S. E. (1999). Managing work role performance: Challenges for twenty-first-century organizations and their employees. In D. R. Ilgen \& E. D. Pulakos (Eds.), The changing nature of performance: Implications for staffing, motivation, and development (pp. 325-365). San Francisco: Jossey-Bass.

Porter, G. \& Tansky, J. (1999). Expatriate Managers: A “Learning Orientations” Approach to Selection and Training. Human Resource Management Journal, 38(1), 47-60.

Pulakos, E.D., Arad, S., Donovan, M.A. \& Plamondon, K.E. (2000). Adaptability in the workplace: Development of a taxonomy of adaptive performance. Journal of Applied Psychology, 85, 612-624.

Schwarz, A., Schwarz, C. \& Rizzuto, T. (2008). Examining the "Urban Legend" of Common Method Bias: Nine Common Errors and Their Impact. HICSS, 41, 441.

Sloan, E. B. (1994). Assessing and developing versatility: Executive survival skills for the brave new world. Consulting Psychology Journal, 46, 24-31. 
Spreitzer, G.M., McCall, M.W. Jr. \& Mahoney, J.D. (1997). Early identification of international executive potential. Journal of Applied Psychology, 82, 6-29.

Sternberg, R.J., Wagner, R.K., Williams, M.W. \& Horvath, J.A. (1995). Testing common sense. American Psychologist, 50, 912-927.

Taylor, E.W. (2000). Analyzing research on transformative learning theory. In J. Mezirow \& Associates (Eds.), Learning as transformation: Critical perspectives on a theory in progress (pp. 285-328). San Francisco, CA: Jossey-Bass.

Vandenbrande, T., Coppin, L. \& van der Hallen (2006). Mobility in Europe. Analysis of the 2005 Eurobarometer survey on geographical and labour market mobility. Dublin: European Foundation.

Van Velsor, E. \& Leslie, J.B. (1995). Why executives derail: perspectives across time and cultures. Academy of Management Executive, 9, 62-72.

Verbruggen, M., Sels, L. \& Forrier, A. (2007). Unraveling the relationship between organizational career management and the need for external career counselling. Journal of Vocational Behavior, 71, 69-83.

Wagner, R.K., \& Sternberg, R.J. (1991). Tacit Knowledge Inventory for Managers. Unpublished research instrument available from authors.

Wechsler, D. (1944). The measurement of adult intelligence. Baltimore: Williams \& Wilkins. White, S. S., Mueller-Hanson, R. A., Dorsey, D., Pulakos, E. D., Wisecarver, M. M. \& Deagle, E. A. (2005). Developing adaptive proficiency in special forces officers (ARI Research Report 1831). Arlington, VA: U.S. Army Research Institute for the Behavioral and Social Sciences.

Wouters K. \& Buyens D. (2006). Managerial learning from on-the-job experiences: an integrative framework to guide future research. Vlerick Working Papers (35), 1-43.

\footnotetext{
${ }^{1}$ Wij gebruikten voor elk van de schalen telkens de oorspronkelijke antwoordcategorieën. Hierdoor was de vragenlijst weinig consistent op dit vlak - er waren open items, en items die gescoord dienden te worden op een
} 
vier-, vijf-, en tienpuntenschaal. Echter, volgens sommige auteurs bevordert variatie in antwoordcategorieën de betrouwbaarheid van een vragenlijst, aangezien de kans op "common method variance" (d.w.z. het zonder differentiatie gelijkaardig antwoorden op alle items in een survey) zo gereduceerd wordt (o.a. Schwarz, Schwarz \& Rizzuto, 2008). 